\author{
A.M. Kamal (iD , M.K. Shnarbekova \\ Al-Farabi Kazakh National University, Kazakhstan, Almaty, \\ e-mail: ardak.kam@gmail.com, e-mail: Meruert.Shnarbekova@kaznu.kz
}

\title{
DESIGNING YOUTH CONSUMPTION STYLE IN SOCIAL MEDIA
}

Social networks are now becoming more common and popular among young consumers in Kazakhstan. Young consumers see the flow of content from firms on social networks, but either this content useful to them. The purpose of the work is to study the impact of social networks on consumption and style design among Kazakhstani youth. The results of youth survey, which were carried out online among consumers aged 21 to 30 years in the city of Almaty, are provided in this article.

The article presents in great detail the concepts by V.I.Ilyin, S.Fris, E.L.Omelchenko, P.Bourdieu, T.Luckman, I.Hoffman, I.N.Ivanova, as well as classical sociological theories (K.Marx, M.Weber, G.Zimmel, T.Veblen, V.Zombart). Socio-economic situation of the individual is considered as a determining factor in consumer behavior.

Although social media has many benefits for consumers, they all boil down to one thing: information. Consumers need information in order to make purchasing decisions quickly and reliably, and social networks have made this information available at hand. Social networks are also a form of expression for consumers and allow their voice to reach the companies and brands that they usually buy. The practical significance of the study contains several recommendations for optimizing the benefits of social networks for young consumers.

Key words: social media, youth, consumption, design of consumption styles, Kazakhstan, shopping

\author{
А.М. Кама^, М.К. Шнарбекова \\ Әл-Фараби атындағы Қазақ ұлттық, университеті, Қазақстан, Алматы қ., \\ e-mail: ardak.kamegmail.com, e-mail: Meruert.Shnarbekova@kaznu.kz \\ Әлеуметтік медиада жастардың тұтыну стилінінің қамыптасуы
}

Әлеуметтік желілер қазіргі уақытта Қазақстанның жас ұрпағы үшін ақпарат алудың кең тараған және танымал құралы болып отыр. Әлеуметтік желілерде фирмалар, брендтер және олардың тауарлары туралы үлкен ақпарат ағыны бар. Тұтынушылар сатып алу туралы шешімді тез және сенімді қабылдау үшін осындай ақпаратты қажет етеАі. Өз кезегінде әлеуметтік желілер бұл ақпаратты қол жетімді етті.

Мақалада әлеуметтік желілердің Қазақстан жастарының белгілі бір тұтыну стилін қалыптастырудағы әсері талданады. Алматы қаласында тұратын 21-30 жас аралығындағы жастардың онлайн-сауалнамасының мәліметтері ұсынылған. Тұтынушылардың мінез-құлқының анықтаушы факторы олардың әлеуметтік-экономикалық жағдайы болып табылатындығын ескере отырып, зерттеу кезінде респонденттердің әлеуметтік-экономикалық әл-ауқатына ерекше көңіл бөлінді, яғни олар әл-ауқатының деңгейі бойынша топтастырылған. Сонымен қатар, жастардың әлеуметтік-экономикалық топтары бойынша тұтынушылық артықшылықтарға салыстырмалы талдау жүргізілді.

В.И.И^ьин, С.Фрис, Е.А.Омельченко, П.Бурдье, Т.Аукман, И.Гофман, И.Н.Иванованың концепциялары, сонымен қатар К.Маркстің, М.Вебердің, Г.Зиммельдің, Т.Вебленьдің, В.Зомбарттың классикалық әлеуметтік теориялары қарастырылады. Алынған деректер негізінде жас тұтынушылар үшін әлеуметтік желілердің артықшылықтарын оңтайландыру бойынша практикалық кеңестер ұсынылған.

Түйін сөздер: әлеуметтік медиа, жастар, тұтыну, тұтыну стильдерінің қалыптасуы, Қазақстан, шоппинг.

\section{А.М. Кама^, М.К. Шнарбекова}

Казахский национальный университет имени аль-Фараби, Казахстан, г. Алматы, e-mail: ardak.kam@gmail.com, e-mail: Meruert.Shnarbekova@kaznu.kz

\section{Конструирование стияя потребления молодежи в социальных медиа}

Социальные сети в настоящее время становятся все более распространенным и популярным средством получения информации для молодого поколения в Казахстане. В социальных сетях 
Аоступен большой поток информации о фирмах, брендах и их товарах. Потребители нуждаются в такой информации, чтобы быстро и надежно принимать решения о покупке. В свою очередь социальные сети сделали эту информацию доступной.

В статье анализируется влияние социальных сетей на формирование определенного потребительского стиля казахстанской молодежи. Представлены данные онлайн-опроса молодых мюдей в возрасте от 21 до 30 мет, проживающих в городе Алматы. Учитывая тот факт, что определяющим фактором поведения потребителей является их социально-экономическое положение, во время исследования особое внимание было уделено социально-экономическому благосостоянию респондентов, которые были сгруппирированы по уровню благосостояния. Также бы^ проведен сравнительный анализ потребительских предпочтений в разрезе социальноэкономических групп молодежи.

Рассматриваются концепции В.И. Ильина, С. Фриса, Е.А. Омельченко, П. Бурдье, Т. ^укмана, И. Гофмана, И.Н. Ивановой, а также классические социологические теории К. Маркса, М. Вебера, Г. Зиммеля, Т. Веблена, В. Зомбарта. На основе полученных данных представлены практические рекомендации по оптимизации преимуществ социальных сетей Аля молодых потребителей.

Ключевые слова: социальные медиа, молодежь, потребление, конструирование стилей потребления, Казахстан, шоппинг.

\section{Introduction}

Social networks are now becoming more widespread and popular among young consumers in Kazakhstan. Currently, companies are realizing how important is to use social networks to communicate with young people. Social media strategies are constantly evolving and becoming better. Companies are experimenting with all kinds of social networks, and this makes the research more interesting.

The problem with the research is that there have been few recent studies on the use of social networks and their impact on consumer behavior of young people in Kazakhstan. In particular, there is little research on the benefits that young consumers can get in developing countries. There is also a need for extended formal research that goes beyond theoretical or predicted results, so that we can gain real knowledge about real-world applications. The purpose of the research is to study the influence of social networks on the consumption and construction of style among Kazakh youth. The subject of the study is the consumption of youth in social networks and its influence on the construction of style. The object of the study is Kazakh youth aged from 21 to 30 years. The research method is a survey of young people, and this article also provides data collection carried out using an online survey of consumers aged 21 to 30 years in Almaty city. The research hypothesis suggests that social networks have a strong influence on the consumer behavior of young people.

Theoretical and methodological basis for the study of youth consumption and social construction styles is the socio-constructivist paradigm, represented by V.I.Ilyin's activity - constructivist approach and his concept of the socio-cultural field. In addition, the methodological basis of the research is the cultural approach ("cultural studies") to the analysis of youth, presented by the concept of C.Frith, where author considers youth as an active subject of consumption. And the interdisciplinary concept of youth cultures by E.L.Omelchenko, which analyzes various phenomena of modern youth everyday practices in terms of differences in their life-style strategies. Also, in classical sociological theories (K.Marx, M.Weber, G.Simmel, T.Veblen, V.Sombart), the socio-economic status of an individual considered as a determining factor of consumer behavior, and consumption in society is determined by its class structure.

The social constructivist direction is represented by the activity-constructivist concept of V.I.Ilyin and the structuralist-constructivist concept of P.Bourdieu. Both concepts allow us to consider consumption as a two-way process. The social environment that has an external character in relation to the individual, with the help of various social institutions, constructs of consumption styles, forms, according to V.I.Ilyin, both the limits of consumer choice and desire. But, on the other hand, this environment is formed by people and exists only to the extent that people reproduce its norms and values in their activities. A person participates in the construction of their own style of consumption, but this construction takes place within the space offered by the social environment. Particular importance for the conceptual definition of social construction is also the reference to the works of P.Berger and T.Lukman, which note that social reality is constructed in the process of joint activity of people, and the key element of construction is the 
person. I.Hoffman's research on the construction of social reality in everyday life, I.N.Ivanova's ideas that the social construction of consumption style acts as a social process that is influenced by many forces and factors.

Theoretical and practical significance of the research is determined by the objective need to identify and analyze the mechanisms of social construction of youth consumption styles. The author's research on the process of designing consumption styles, development of the typology of consumption styles, identification of the main mechanisms and agents of their construction contribute to a deeper interdisciplinary understanding of the nature and mechanisms of social construction of youth consumption styles.

The results of the research allow us to expand the theoretical concepts of consumer sociology and youth sociology as areas of national sociology. The practical significance of the research is that the results obtained in the study can serve as a basis for developing programs on youth policy in accordance with the real needs and everyday practices of young people.

\section{Methodology}

Social networks are technologies that facilitate social interaction, make collaboration possible, and provide discussion between stakeholders. These technologies include blogs, wikis, tools for sharing media (audio, photo, video, text), networking platforms (including Facebook, Instagram, Vkontakte, Facebook) and "virtual worlds" (Bryer, Zavattaro, 2017:325). One of the advantages of the Internet is that it allows businesses to reach customers around the world, so that customers can research, select, and purchase products and services from businesses around the world.

Social media is the background in which social networking occurs, and it completely changes the way consumers make their purchasing decisions. Social media is very interactive, and users share information and process it with others (Kailani, Kumar, 2018:76). Manufacturers and firms have benefited from this new channel, and most firms now carry out a significant portion of their marketing through social media, allowing them to engage their consumers in a more personal and cost-effective way. Thanks to technological advances, social networks provide access to reliable information at convenient times, even when customers are at home, and therefore they can make comparisons and better monitor from anywhere in the world. Of course, this is directly related to the style of consumption. Youth consumption styles act as a social construct that is formed both by the social environment, which has an external character in relation to the person, and by the person himself, reproducing the norms and values of the environment in their everyday consumer practices. The methodological possibility of such consumption styles consideration is determined by the application of a participatory approach, which is a synthesis of a socio-constructivist methodological direction, the concept of a socio-cultural field, and a culturological approach to the analysis of youth consumption styles (Prasad, Totala, 2014:166). The style of youth consumption is a complex phenomenon that manifests itself primarily in everyday consumer practices and built by young people themselves within the socio-cultural spaces in which they fit (Palmer, Koenig-Lewis, 2019:162).

Youth consumption styles are presented as a space of everyday consumer practices and described based on three principles: "spatial", "situational", and "style". The "spatial" principle allows us to consider the space of consumer practices as divided into peculiar "consumption zones", or using V.Ilyin's terminology, "socio-cultural fields" of consumption (Ilyin, 2014:25). The "situational" principle describes the context of consumer practices and aimed at the subject aspect - the description of the subject and the situation of consumption. The principle of "style" is directly aimed at describing the style of consumption, while the research focus shifts to describing how consumer practices are implemented (Ilyin, 2014:29).

The typology of student consumption patterns is based on three main parameters: the source of attracting resources, the way resources are distributed, and the destination of consumer practices. Depending on the source of attracting resources, located in the "I-others" continuum, there are two styles of consumption: "independent" (the individual primarily attracts his own resources) and "borrowing" (the individual borrows the resources from others). Depending on the method of resource allocation, there are three styles of consumption: "Optimal" (consumer practices are maximally calculated, a person has a clear idea of the goal and compares it with the resources that need to be spent on achieving it), "Economical" (the individual is guided primarily by considerations of saving various resources), "Spontaneous" (the individual enjoys consumer practices "here and now", his consumption is often spontaneous, and consumer practices are subjected to stress relief, entertainment). Depending on the addressee of consumer practice (located in the continuum "I-others") consumption styles differ 
in terms of the consumption process and in terms of the consumption result. From the point of view of the consumption process, consumption styles are considered as an "individual" (consumer practices are mostly individual) and "joint" (preference is given to joint consumer practices). In terms of the result of consumption, "consumption as representation" (consumer practices are focused on others, evaluated by others) and "consumption as self-realization" (consumer practices are focused on themselves, self-realization) differ from each other (Nair, 2016:45). Thus, we have formulated two research questions: (1) What factors of individual, family and social levels have an impact on the consumer demand of young people? (2) What factors of these three levels have the main effect of calling for action?

\section{Search procedure and review parameters}

The main active agents in building youth consumptionstylesare socialinstitutions (educational institutions (school, university), family institutions, media institutions, peer groups ("peer groups")). Main mechanisms for building consumption styles in these institutions are existing mechanisms for transmitting and perceiving consumer standards and models, which are manifested in three main components: resource opportunities (primarily economic resources), the "cultural program" (manifested in a system of norms and values that regulate consumer behavior of students), the social and communication system (the language of consumer practices). Each of these components, in turn, is an object of social management, which allows us to consider the very construction of consumption styles as a manifestation of management (Adams, 2012:326).

This research is based on primary data, main purpose of which is to provide information about the patterns of social networks use when making purchasing decisions. Article uses a combination of primary and secondary data to understand how consumers benefit from social networks. The research is conducted in the commercial and financial capital of Kazakhstan, Almaty. Data is collected through an online consumer survey of 145 social media users aged 21 to 30 . The information was obtained directly from respondents via the Internet from February 5 to March 10, 2020. We have specially chosen this period, because in this period there are two holidays (like Valentine's Day and $8^{\text {th }}$ of March). Responses to this questionnaire then were analyzed to find out why people really use social networks and what benefits they get from them as consumers. We used a convenient sampling method, which implies a sample with unreliability.

\section{Results}

Value Social networks are important for 52\% of respondents and especially important for $17 \%$. They don't matter much to the $23 \%$, whereas they don't matter at all to the $8 \%$. Women seem to think that social media is much more important than men, with $74 \%$ considering it important compared to $26 \%$ of men and $84 \%$ considering it very important. Instagram, Facebook and WhatsApp have proven to be the most widely used social networks used in Mumbai. Facebook is one of the most widely used social networks in the world, as well as the most flexible in terms of what content can be published. Its popularity can be attributed to the wide variety of content it hosts, including text, images, videos, and more. The growth in the number of smartphones has sparked the popularity of What's App, which is now not only the main messaging app for mobile phones, but is itself a mobile social platform. The growth of What's App signals about the popularity and potential of mobile social networks.

95.8\% use social media to keep in touch with friends and family, which shows that social media is still perceived as an interaction tool rather than anything else, and most of its other benefits are secondary. However, the second most frequently mentioned reason is "follow the news and celebrities", which was mentioned by $50.3 \%$ of respondents. This shows how social networks have made people bigger consumers of news by making it easy to read news on websites like Facebook or Twitter. Most news agencies now have a Facebook and Twitter pages that make news more interactive and reader-oriented. In addition, most celebrities now use online social networks, which have made them more accessible to their fans, which can also be called consumers of the celebrity brand. $33.6 \%$ of respondents use social networks to track trends, which again benefits consumers as a source of information.

$70.6 \%$ used social media to follow news pages, which only supports the early claim those social media benefits news readers/consumers by allowing them to follow news agency pages and get the latest news directly in their feed. $60.3 \%$ also followed fashion and style brands, which show how consumers can use social media to shop online by following their favorite brands online. $50 \%$ of respondents follow social causes online, which makes it easier for them to donate and volunteer for causes, not to mention raise awareness about them. 
$41.9 \%$ follow celebrities, which again confirms that social media has made celebrities more accessible to their celebrity fans/consumers.

$39.7 \%$ follow technology pages. These pages not only help consumers make better purchasing decisions, but also show them how to make the best use of their existing technological devices. $32.4 \%$ follow social network icons, such as bloggers and weiners (video bloggers). Although these icons are more popular among young people, they benefit people of all ages. Not only do they allow consumers to follow topics that interest them, but they often recommend products to their readers and, like technology pages, show how consumers can make the most of what they already have. Consumers who shop online can benefit the most from social media, since most of the content on social media is targeted at online shoppers. Only $20.3 \%$ of respondents said that they never make purchases online. However, the majority of respondents' answers $(81.2 \%)$ relate to a lower scale of online shopping frequency, which shows that although social networks can have an impact on consumers, change is slow, as most people still prefer personal purchases. What about the impact of social media on shopping, $65.7 \%$ of respondents admitted that a social media post "sometimes has some influence" on purchasing decisions (see figure 1).

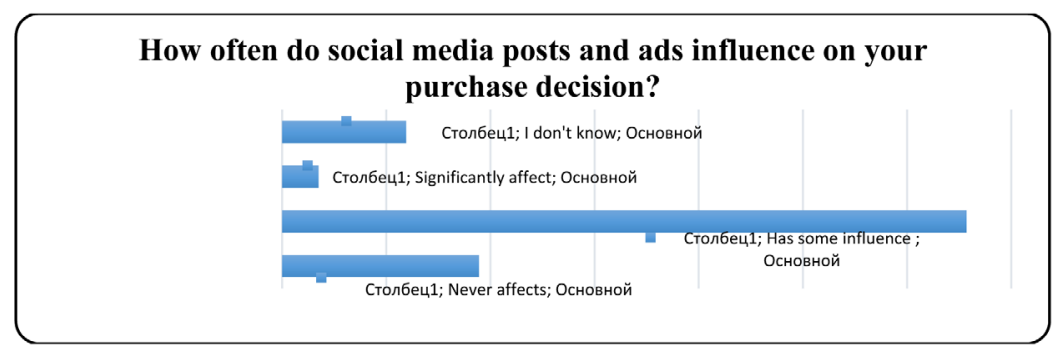

Figure 1 - Influence of social networks on the purchase

While this may not strongly indicate the importance of social media to consumers, when we consider that most people are unwilling to disclose or unaware of how influential an ad campaign can be, we can safely conclude that brands' social media posts influence to customers. This can be useful for consumers by providing information about products and trends, as well as personalizing the advertising process. However, it is also possible that consumers will be forced to buy things that they do not need. This may be one of the disadvantages of social media for consumers.

Also, during the analysis, we found that $38 \%$ of respondents block ads and advertising messages in social networks, although only $6.3 \%$ often block them. However, an excess of such messages in social networks not only leads to overload of information for the consumer, but is often undesirable. This demonstrates the disadvantages of social networks for consumers. But blocking ads on social media means that consumers can't take benefits of other social media advantages, such as being able to track trends, track discounts and offers. To maximize the benefits of social networks, you need to find a balance between them. We also sought to understand whether consumers check information online before purchasing a product (see figure 2).

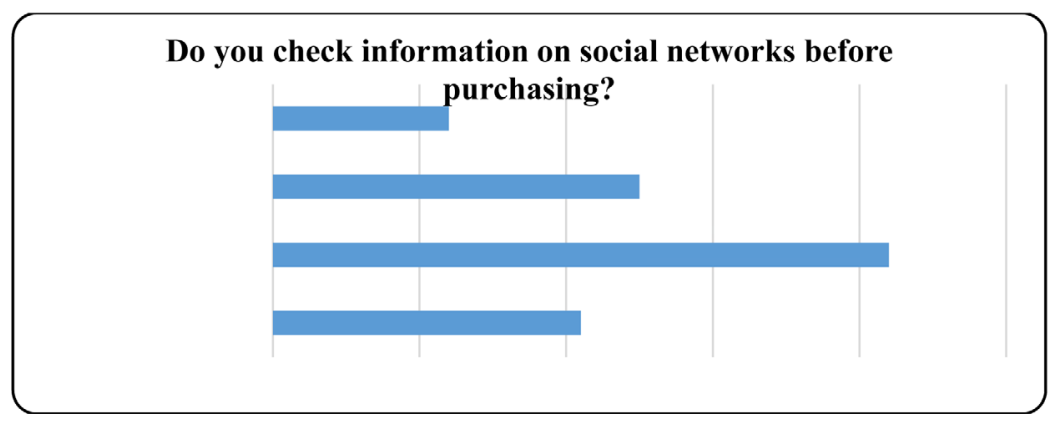

Figure 2 - Checking information before purchasing on social networks 
In response to this question, $25 \%$ said that they check information, $42 \%$ check it sometimes, $21 \%$ of respondents do not check this, while $12 \%$ claim that they did not think about it and noted "I do not know". Analysis of the relationship between consumer income and attitudes to product verification on the Internet shows that people with lower income levels often check all information about a product on the Internet before making a decision to buy it.

\section{Discussion}

The impact of social media among young people cannot be ignored. Not only the number of social network users are increasing, but also types of social networks and number of social network platforms. Now all apps have a "social" element, even a normal app whose main purpose is another, can act as a social media platform, connecting users to each other. In these circumstances, social networks should play a role in the lives of consumers. Social networks are undoubtedly important and valuable for business. According to the study, social networks can have several advantages for young consumers. While social media has many advantages for consumers, they all come down to one thing: information. Consumers need information to make purchasing decisions quickly and reliably, and social media has made this information available at hand. Social media is also a form of expression for consumers and allows their voice to reach the companies and brands they usually buy. The younger generation in Kazakhstan lives more in the virtual world than in the real world, and this has become a kind of addiction. This platform is also well suited for those who are looking for attention. Companies in Kazakhstan are significantly increasing their spending on social media marketing, although the effectiveness of this requires further study. In this study, we would like to suggest that each company chooses the most appropriate social networks according to the characteristics of the organization.

\section{Conclusion}

From the many consumer decision models, the model that is basically the main, offers three important steps: searching for information, evaluating various alternatives, and post-purchase behavior. In this way, consumers evaluate various products and then make a decision. This becomes the most important reason why today all corporate and commercial companies should be present in social networks. This is because $74 \%$ of consumers rely on social media when making a purchase decision.
Businesses and social media platforms can reduce the harm caused by disadvantages and optimize the benefits of social media for consumers in several ways, such as:

1. Filtering ads and advertising messages by audience, so that they reach only the target segment.

2. Improve the security of websites and servers to avoid hacking and information leaks.

3. Watch out for pages that are possible scams and appear unreliable. These pages should be deleted immediately.

4. Use of specialized social networks in contrast to conventional social networks. Although the audience is decreasing, it becomes more likely that the message reaches the target segment and doesn't bother other social media users.

5. Showing customers that you really care about their experience

6. Continuous tracking, conducting surveys and monitoring keywords in social networks.

7. Create long-term customer loyalty through digital thank-you notes, personalized messages, and other interactions.

Young consumers are also responsible for their social media experience and can expand it by using specialized social networks, where they are more likely to find information that helps and interests them. Also, do not provide personal information to ensure Internet security. Check the security of the website they are using. Search social media pages by topic to find more variety that interests them.

These proposals, if implemented, could ensure that social media is not only a platform for firms to promote to the market, but that consumers of the platforms can benefit the most if companies find that their social media campaigns are not working. The answer is no, to put the idea on hold, but update this. Today, the Kazakh consumer is extremely cautious about how they spend their hard-earned rupees. Companies should create innovative pages that contain the correct data and feedback from satisfied customers, rather than populate the pages with company information. The future of social media marketing in Kazakhstan looks very promising. The social media platforms themselves are developing and undergoing stages of innovation along with new features. Companies should test different strategies, take note of which ones work best, and focus on these strategies. Treating social media as a means of serving customers and enriching the overall shopping experience is vital for business in the future. In this way, businesses can create loyalty and communicate with their commitment to customers. 


\section{References}

Adams S., (2012) Factors Affecting young consumers online purchase intention in social media websites. Journal of Procedia -Social and Behavioral Sciences, no 40(12), pp. 326-333.

Bernhardt J.M., Mays D., (2017) Social marketing at the right place and right time with new media. Journal of Social Marketing, no 2(12), pp. 130-137.

Bryer T.A., Zavattaro S.M., (2017) Social media and public administration: Theoretical dimensions and introduction to the symposium. Journal of Administrative Theory \& Praxis, no 33 (12), pp. 325-340.

Cha J., (2019) Shopping on Social Networking Websites: Attitudes towards real versus virtual items. Journal of Interactive Advertising, no 10(4), pp. 77-93.

Crozier D., Mclean F., (2017) Consumer Decision-Making in the Purchase of Estate Agency Services. The Service Industries Journal, no 17(2), pp. 278-286.

Georgi D., Moritz M., (2015) The quality of electronic customer-to customer interaction. Journal of Retailing and Consumer Service, no 20 (8), pp 11-19.

Ilyin V.I., (2014) Sociology of Consumption. Journal of Sociological Society, no 22(5), pp. 25-39.

Kailani M., Kumar R., (2018) Investigating Uncertainty Avoidance and Perceived Risk for Impacting Internet Buying: Three National Cultures. International Journal of Business and Management, no 6(5), pp. 76-92.

Koesler K., (2018) Cultural Influence on Consumers' Usage of Social Networks and its' Impact on Online Purchase Intentions. Journal of Retailing and Consumer Services, no 18 (12), pp. 348-354.

Laroche M., Richard M., (2017) The effects of social media based brand communities on brand community markers, value creation practices, brand trust and brand loyalty. Journal of Computers in Human Behavior, no 28(5), pp. 165- 176.

Levykin I.T., Reizema Ya.V., (2015) Social style as a research category of lifestyle. Institute of Sociology, no 4(11), pp. 166-178.

Nair M., (2016) Understanding and measuring the value of social media. The Journal of Corporate Accounting \& Finance, no 22(3), pp. $45-51$.

Palmer A., Koenig-Lewis N., (2019) An experiential, social network based approach to direct marketing. Direct Marketing: An international Journal, no 3(13), pp. 162- 176.

Prasad S., Totala N.K., (2014) Social Media and Customer Purchase Decision. American International Journal of Research in Humanities, Arts and Social Sciences, no 1421 ), pp. 166-171.

Shankar V., Inman J., Mantrala M., Kelley E., (2018) Innovations in Shopper Marketing: Current Insights and Future Research Issues. Journal of Retailing, no 87(13), pp 29-42. 